\title{
Infuusiohoidot turvallisesti kotona
}

\section{- selvitys älykkään teknologian mahdollisuuksista}

Eija Kivekäs ${ }^{1}$, Eija Toppinen ${ }^{1}$, Hannu Kokki ${ }^{2}$, Pekka Mäntyselkä ${ }^{3,4}$, Ulla-Mari Kinnunen ${ }^{1}$, Juhamatti Huusko ${ }^{1}$, Kaija Saranto ${ }^{1}$

${ }^{1}$ Sosiaali- ja terveysjohtamisen laitos, Itä-Suomen yliopisto, Kuopio, Finland; ${ }^{2}$ Kliinisen lääketieteen yksikkö, ItäSuomen yliopisto, Kuopio, Finland; ${ }^{3}$ Kansanterveystieteen ja kliinisen ravitsemustieteen yksikkö, Itä-Suomen yliopisto, Kuopio, Finland; ${ }^{4}$ Pohjois-Savon sairaanhoitopiirin perusterveydenhuollon yksikkö

Eija Kivekäs, Sosiaali- ja terveysjohtamisen laitos, Itä-Suomen yliopisto, Kuopio, FINLAND. Sähköposti: eija.kivekas@uef.fi

\section{Tiivistelmä}

Tässä tutkimuksessa kartoitettiin infuusiohoitojen määrää ja laatua terveydenhuollossa ja arvioitiin, miten älykkään teknologian avulla infuusiohoitoa voidaan toteuttaa turvallisemmin, vaikuttavammin ja kustannustehokkaammin. Tiedonkeruu tehtiin yliopistollisen sairaalan osastoilla ja perusterveydenhuollon kotisairaalayksiköissä tai vastaanotoilla. Yhdistämällä eri tiedonhankintamenetelmiä saatiin kuva infuusiohoitojen nykytilanteesta kotihoidossa sekä lääkäreiden ja sairaanhoitajien vastaanotoilla. Kotisairaalatoiminnan käynnistäminen oli muuttanut potilasvirtoja, jolloin vuodeosastolla pelkästään infuusiohoidon takia olevat potilaat olivat vähentyneet. Yhteistyö ensihoidon kanssa oli edellytys ympärivuorokautiseen kotisairaalatoimintaan. Infuusiohoitojen etämonitorointi ei ole käytössä ja tekniikkaa hyödynnetään hyvin vähän infuusiohoidoissa. Terveydenhuollon ammattilaiset olivat valmiit käynnistämään infuusiohoitoihin liittyvän etämonitoroinnin ja siten ottamaan käyttöönsä nykyistä enemmän älykkään teknologian tuomia mahdollisuuksia.

Avainsanat: kotihoito, lääkehoito, infuusio, teknologia, älykäs teknologia

\section{Abstract}

The purpose of the research project titled "Safety at Home and in Institutional Care: Utilizing remote monitoring and smart pump -technology in infusion care" was to identify the profile of patients, who require institutional care for infusion therapy for medical and nutrition management, in district hospital area. The digital technology, monitoring, and action models currently use is mapped. The overall purpose is to study the extended implementation of infusion care at home, utilizing smart technology. The data was collected through interviews and statistics. The aim was to explore how home infusion therapy is used, and how willing health care providers are to change current practices. The results showed that infusion therapy was common at outpatient clinics and quite common at home care. Collaboration with home care and emergency care made the infusion therapy possible at patient's home. The use of smart technology in home care was less usual. The participants were enthusiastic and willing to use smart technology in infusion care and remote monitoring of patients' status.

Keywords: home care, medication, infusion, technology, smart technology 


\section{Johdanto}

Teknologian käyttö avaa uusia mahdollisuuksia lääkehoidon toteutukseen niin hoitolaitoksissa kuin potilaan kotona. Mobiili terveysteknologia (mobile health, mHealth) mahdollistaa potilaan etämonitoroinnin, jossa teknologiaa hyväksikäyttämällä hallitaan, tarkkaillaan ja hoidetaan potilaan vointia ja hoidon toteutusta etäyhteyden kautta. Näillä toiminnoilla on mahdollista tehostaa ja kehittää terveydenhuollon toimintayksiköiden toimintaa. [1] Sosiaali- ja terveydenhuollon teknologia liittyy hoitoon, hoivaan, toimintakyvyn vajeiden ja heikentymisen ehkäisyyn ja hidastamiseen, kompensointiin sekä kuntoutukseen [2]. Teknologiaa käytetään hoivaja hoitotilanteissa, laitoksissa ja kotona, itsenäisesti ja avustettuna. Osana sosiaali- ja terveydenhuollon palveluja teknologia on nähtävä laajana järjestelmänä, joka sisältää tutkimusta, suunnittelua ja käyttöä sekä arviointia. Se edellyttää vahvaa monitieteisyyttä, moniammatillisuutta ja asiakas- ja potilaslähtöisyyttä.

Terveydenhuollon laitteiden käyttö ja markkinoille saattaminen ovat säädeltyä ja valvottua. Lähtökohtana terveysteknologian hyödyntämisessä on potilaan etu ja potilasturvallisuus. Teknologian kehitys on nopeaa ja terveydenhuolto on mitä suuremmassa määrin riippuvainen erilaisista teknisistä laitteista. Kotiin tuotavat terveydenhoitopalvelut ovat lisääntyneet ja kansalaisten aktiivisuutta oman terveyden ylläpitämisessä on haluttu lisätä. Esimerkiksi diabeteksen hoidossa on jo vuosia tallennettu verensokeriarvot internet-pohjaiseen ohjelmaan, jota terveydenhuollon ammattilaiset ovat hyödyntäneet hoidon arvioinnissa. [3-7]

Tässä tutkimuksessa selvitettiin sairaanhoitopiirin alueella, erityisesti avohoidossa ja kotisairaalassa annettavia infuusiohoitoja keväällä 2016. Lisäksi selvitettiin, millaisia valmiuksia terveydenhuollossa on toteuttaa infuusiohoitoa kotona älykkään teknologian avulla etämonitorointia kehittämällä.

\section{Infuusiohoidot avoterveydenhuollossa ja potilaan kotona}

Kotisairaanhoito ja kotisairaalahoito ovat hoito- ja palvelusuunnitelman mukaista määräaikaista potilaan asuinpaikassa, kotona tai siihen verrattavassa paikassa moniammatillisesti toteutettua terveyden ja sairaanhoidon palvelua. Hoito voi olla perusterveydenhuollon, erikoissairaanhoidon tai niiden yhdessä järjestämää toimintaa. Kotisairaalan potilaat ovat usein akuuttihoitoa tarvitsevia työikäisiä, vanhuksia tai pitkäaikaista hoitoa tarvitsevia henkilöitä, kuten infektio- ja syöpäsairauksia tai muita vaikea-asteisia pitkäaikaissairauksia sairastavia. (Terveydenhuoltolaki 1326 / 2010, 3.luku 25 $\S$.$) Lääkehoito on osa potilaan kokonaisvaltaista hoitoa$ ja keskeisessä osassa kotisairaalatoiminnassa. Onnistunut lääkehoito perustuu potilaan hoitoon sitoutumiseen ja siksi potilaan tulee olla tietoinen hoidon tavoitteesta sekä lääkkeen käyttötarkoituksesta. Myönteinen esimerkki kotisairaalatoiminnan käynnistämisestä on Kuopion Enter-hanke, jossa uudella kotisairaalatoimintamallilla palvelut vietiin potilaan kotiin $[8,9]$.

Enter-hankkeessa potilaiden palaute oli myönteistä ja kustannuslaskelmat seurantajakson aikana osoittivat kotisairaalakäyntikerran hinnassa (noin $76 €$ /käynti) merkittävän eron perusterveydenhuollon (noin $240 € / v r k$ ) ja erikoissairaanhoidon (noin 650€/vrk) sairaalahoitohoitopäivänmaksun keskiarvoon. Kansainvälisesti infuusiohoitojen toteutuksesta potilaan kotona on saatu myönteisiä tuloksia [10-13]. Avohoidossa toteutettavasta laskimoon annettavasta antibioottihoidosta käytetään nimitystä Outpatient Parenteral Antimicrobial Therapy (OPAT) [10]. OPAT-toiminnasta vastaa tiimi, jossa sairaanhoitaja vastaa potilaan ohjaamisesta, tuesta ja hoidon toteutuksesta, lääkäri vastaa hoidosta ja tiimiin kuuluvat lisäksi infektiolääkäri ja farmaseutti $[10,11]$. Toiminnan myönteisiä vaikutuksia potilaille arvioitiin olevan hoitopaikan valintamahdollisuus ja arkeen paluun nopeutuu. Vastaavasti hyödyt organisaatiolle olivat vuodepaikkojen vapautuminen akuuttihoidon käyttöön ja elektiivisen toiminnan lisäkapasiteetti [10].

Infektiot ja antibioottihoito ovat yksi yleisin syy potilaan ohjautumisessa perusterveydenhuollon vuodeosasto- 
hoitoon [14]. Kotisairaalahoidon kehittyessä ja laajentuessa on mahdollista, että OPAT-toiminnan tapaista tiimityötä olisi mielekästä kehittää myös Suomessa $[10,15]$.

\section{Kotona käytettävien lääkintälaitteiden turvallisuus}

Olosuhteet potilaiden kotona vaihtelevat ja tämä tuo haasteensa kotona käytettävälle teknologialle. Käytettäessä terveydenhuoltolaitteita kotona on huomioitava lääketieteellinen indikaatio, minkä vuoksi laite luovutetaan kotiin. Lisäksi on huomioitava potilaan tarve ja valmistajan ilmoittama laitteen käyttötarkoitus. Kotona tällä hetkellä käytettäviä laitteita ovat muun muassa verenpainemittari, verensokerimittari, INR-mittarit (veren hyytymisarvoa mittaava laite), kipupumput, dialyysilaitteet ja seurantalaitteet. [7]

Ennen laitteen luovuttamista kotikäyttöön on varmistettava, että laite soveltuu kotona käytettäväksi. Vastuu käyttöpaikan turvallisuudesta on terveydenhuollon toimintayksiköllä ja terveydenhuollon ammattihenkilöillä. Laitteen luovutuksesta päättävä hoitava lääkäri vastaa siitä, voidaanko laite turvallisesti luovuttaa kotiin, silloinkin kun laitetta voidaan valmistajan mukaan käyttää kotona. Kotona käytettävässä laitteessa tulee olla asetettuna hälytysrajat ja muut säädöt, kuten mahdollinen salasanasuojaus, jolla estetään asetusten muuttaminen. Sosiaali- ja terveydenhuollon toimijoiden velvollisuus on huolehtia terveydenhuollon laitteiden toimintakunnosta, käyttöohjeiden saatavuudesta ja noudattamisesta sekä käyttökoulutuksesta (Laki 629/2010) [7].

Kotona käytettävien laitteiden testauksessa korostuu käytettävyys, sillä käyttäjä voi olla terveydenhuollon ammattilainen, asiakas, potilas tai lähiomainen. Kotona käytettävien lääkintälaitteiden testauskriteerit ovat tiukemmat kuin laitos ympäristössä, koska ei voida tietää millaisessa ympäristössä laitetta käytetään. Kotona käytettäville sähkölaitteille on olemassa erilaisia teknisiä vaatimuksia: lämpötilan $+5{ }^{\circ} \mathrm{C}-+40{ }^{\circ} \mathrm{C}$, kosteuden $15 \%$ - 93\%, paineen $700 \mathrm{hPa}-1060 \mathrm{hPa}$ sekä koteloinnin ja merkintöjen osalta [16]. Käyttäjän tulee tunnistaa yleisimmät virheilmoitukset, esimerkiksi patterin loppuminen. Kotona käytettävän laitteen säännöllisestä huollosta ja kalibroinnista huolehtii laitteen luovuttanut yksikkö. [7]

Älykkäät infuusioautomaatit tukevat turvallisen lääkehoidon toteutusta ja voisivat mahdollistaa myös potilaan itsenäisen infuusiohoidon toteutuksen. Teknologian mahdollisuudet parantaa kotona annettavan hoidon laatua ja tehokkuutta erityisesti lääkehoidon prosesseissa ovat kiistattomat $[17,18]$. Toisaalta tutkimukset osoittavat, että lääkintälaitteiden käyttöönotto on myös lisännyt vaaratapahtumia ja vaarantanut potilasturvallisuutta $[19,20]$. Lääkityspoikkeamien ja riskien vähentämiseksi on kehitetty älykkäitä infuusioautomaatteja (Smart Infusion Pump), joihin on integroitu laskimonsisäisesti annosteltavat lääkevalmisteet sisältävä lääkeopas (Drug Library) sekä lääkehoidon toteutusta tukevia ja valvovia toimintoja [21,22].

Vaihtoehto perinteiselle sairaala tai polikliiniselle hoidolle on potilaan etämonitorointi kotihoidossa, jonka on todettu olevan turvallinen ja tehokas [4]. Seurannan tiedonsaanti nopeuttaa ongelmien havaitsemista ja parantaa laitehoidon turvallisuutta sekä vähentää seurantakäyntejä.

Lääkintälaitteiden etäkäyttö ja hoidon monitorointi kotona vaatii tietosuoja- ja tietoturvakysymysten huomioimista. Asiakkaiden ja potilaiden tulee pystyä luottamaan järjestelmän turvallisuuteen. Tietojen tulee siirtyä turvallisesti ja oikealla tavalla, ja heidän yksityisyys turvaten. On todettu, että luottamuksen puute järjestelmää kohtaan vähentää käyttäjän aktiivisuutta syöttää järjestelmään säännöllisesti tarvittavaa tietoa, mikä johtaa siihen, että tietoa ei voida käyttää potilaan hoidon arvioinnissa. Hoidon huono laatu taas vähentää luottamusta kotona käytettävien sovellusten käyttöön [23]. Järjestelmän luotettavuus ja tietojen saatavuus sekä eheys ovat keskeisiä kriteereitä etäkäytössä oleville laitteille. [24] Kotoa toteutettavassa tiedonsiirrossa tullaan törmäämään haasteisiin: miten kotona syntyvä tiedon laatu varmennetaan, voiko tietoon luottaa, miten tieto on syntynyt ja miten tunnistaa luotettavasti osapuolet (lähettävä ja vastaanottava taho). Lisäksi on huomioitava erikoistilanteet, jolloin tiedonsiirto ei toimi 
tai laitteiden suojaaminen on murrettu (hakkeroitu). [25-27.]

\section{Tutkimuksen tarkoitus ja tutkimuskysymykset}

Tämän tutkimuksen tarkoituksena on selvittää, millaisia valmiuksia terveydenhuollossa on toteuttaa infuusiohoitoa kotona älykkään teknologian avulla etämonitorointia kehittämällä. Tutkimus hahmottaa kuvan kotisairaalatoiminnasta yhden sairaanhoitopiirin alueella. Tutkimuksessa haastateltiin keskeisiä toimijoita ja toimintatilastojen avulla selvitettiin infuusiohoitojen määrää avoterveydenhuollossa.

\section{Tutkimuskysymykset:}

1) Millaisia infuusiohoitoja toteutetaan avoterveydenhuollossa ja kotisairaalassa?

2) Millaiset ovat infuusiohoitojen toimintamallit avoterveydenhuollossa ja kotisairaalassa?

3) Millaista teknologiaa hyödynnetään infuusiohoitojen toteutuksessa?

\section{Aineisto ja menetelmät}

Tutkimuksen kohteena oli avoterveydenhuollossa ja kotisairaalassa annettavat infuusiohoidot eräässä sairaanhoitopiirissä keväällä 2016.
Tutkimus käynnistyi selvittämällä avoterveydenhuollossa infuusiohoitoja tarvitsevien potilaiden määrä, käytössä olevat toimintamallit sekä lääkehoitojen määrä ja laatu. Aineisto kerättiin haastattelemalla terveydenhuollon henkilöstöä $(n=20)$ avoterveydenhuollon vastaanotoilta, kotisairaalasta, kotihoidosta, ensihoidosta ja vuodeosastoilta $(n=10)$. Infuusiohoitojen lukumäärätiedot koottiin perusterveydenhuollon toimintoluokitustiedoista (SPAT-koodi) [28] ja infuusiohoitojen laatu apteekin infuusiolääkkeiden jakeluyksikkötiedoista.

\section{Tulokset}

Haastatellut henkilöt $(n=20)$ olivat terveydenhuollon johtajia, kuten osastonhoitajia ja - lääkäreitä, ylihoitajia ja - lääkäreitä, jotka vastasivat infuusiohoitojen toteutuksesta. Haastatteluihin osallistui lisäksi sairaanhoitajia, jotka toteuttivat infuusiohoitaja vastaanotoilla, vuodeosastoilla ja potilaan kotona.

\section{Infuusiohoitojen määrä ja laatu}

Infuusiohoitojen lukumäärä selvitettiin SPATkoodistokirjauksen perusteella. SPAT 1254 -koodia (Lääkkeen anto. Suun tai muun ruumiin aukon kautta tai silmän pinnalle tai inhalaationa terveydenhuollon yksikössä annettava lääke) käytetään, kun potilaalle on vastaanottokäynnillä annettu lääkettä. SPAT 1255 koodia (Suonensisäinen lääkehoito) käytetään silloin, kun lääke on annettu laskimoon. (Taulukko 1).

Taulukko 1: Vastaanottokäyntien SPAT 1254 ja SPAT 1255 koodien asiakas- ja käyntimäärät esimerkki perusterveydenhuollon avohoidossa $2011-2015$.

\begin{tabular}{ccccc}
\hline & \multicolumn{2}{c}{ SPAT 1254 } & \multicolumn{2}{c}{ SPAT 1255 } \\
& Asiakkaita & Käyntejä & Asiakkaita & Käyntejä \\
\hline 2011 & 1160 & 49036 & 22 & 50 \\
2012 & 3545 & 375907 & 89 & 306 \\
2013 & 3971 & 575312 & 134 & 678 \\
2014 & 4243 & 591162 & 218 & 947 \\
2015 & 4383 & 615521 & 210 & 927 \\
\hline
\end{tabular}


Haastatteluaineiston perusteella osattiin ennakoida, että SPAT-koodien lukumäärät eivät välttämättä anna oikeaa kuvaa infuusiohoitojen kokonaismääristä avohoidossa. Koodien käyttö on lisääntynyt vaiheittain vuodesta 2011.

Apteekista toimitettujen antibioottien (J01) injektio- tai infuusiolääkkeiden jakeluyksikkömäärää verrattiin SPAT 1255 koodien lukumäärään. Yhteen tutkimusalueen terveyskeskukseen toimitettiin vuoden aikana yli 20000 antibiootti (J01) injektio- tai infuusiolääkkeiden jakeluyksikköä. Kefuroksiimi oli yleisin lääkeaine ja sen jakeluyksikkömäärä oli yli 10000 vuodessa. Lääkärin ja sairaanhoitajan vastaanotolla kyseisessä terveyskeskuksessa oli kirjattu vajaat 1000 SPAT-1255 (infuusiolääkehoito) koodimerkintää ja antibioottien jake- luyksikkömäärä vastaavana ajanjaksona oli 732. Lisäksi infuusiohoitojen jakaantumista tarkasteltiin ikäryhmissä. Ikäryhmistä 18-64-vuotiaat olivat suurin ryhmä, joka hakee infuusiohoidon päivittäin tai useasti päivän aikana terveyskeskuksen vastaanotolta (Taulukko 2). Kotisairaalassa yli 65-vuotiaat olivat suurin ikäryhmä, joka sai infuusiohoitoja.

Antibioottihoito valittiin tarkastelun kohteeksi haastattelutuloksen perusteella, jota vahvistivat kotisairaalan toimintatiedot (Taulukko 3), joissa infektio tai epäselvä infektio olivat määrällisesti eniten kirjattu diagnoosi. Muita terveyskeskuksen vastaanotoilla laskimoon annettavia lääkehoitoja olivat muun muassa rautainfuusio, immuunipuolustuksen lääkehoito, verituotteet, syöpähoitoihin liittyvät lääke- ja nestehoito.

Taulukko 2. Avoterveydenhoidossa SPAT 1255 (Suonensisäinen lääkitys) lukumäärät ikäryhmissä vuosilta 20112015.

\begin{tabular}{lcc}
\hline Vuosi & Ikäryhmä & SPAT 1255 (lukumäärä) \\
\hline 2011 & $18-64 v$ & 40 \\
& $65 v$ tai yli & 10 \\
\hline 2012 & alle $18 v$ & 2 \\
& $18-64 v$ & 228 \\
& $65 v$ tai yli & 76 \\
\hline \multirow{2}{*}{2013} & $18-64 v$ & 469 \\
& 65 v tai yli & 209 \\
\hline \multirow{2}{*}{2015} & alle $18 v$ & 8 \\
& $18-64 v$ & 401 \\
& $65 v$ tai yli & 538 \\
\hline & alle $18 v$ & 1 \\
& $18-64 v$ & 382 \\
& $65 v$ tai yli & 544 \\
\hline
\end{tabular}

Taulukko 3. Potilaiden diagnoosit vuosina kotisairaalassa vuosina 2013-2015.

\begin{tabular}{lccc}
\hline Diagnoosi & $\mathbf{2 0 1 3}$ & $\mathbf{2 0 1 4}$ & $\mathbf{2 0 1 5}$ \\
\hline Infektio & 81 & 164 & 170 \\
Muu / epäselvät infektiot & 36 & 184 & 232 \\
Divertikuliitti & 4 & 9 & \\
Nesteytys & 6 & 40 & 27 \\
VAC-hoito (Vacuum Assisted Closure) & 1 & 9 & 11 \\
HTA-käynnit (Hoidon Tarpeen Arviointi) & & & 33 \\
Kipupumppu & & & 8 \\
Saattohoito & & & 9 \\
\hline
\end{tabular}




\section{Infuusiohoitojen toimintamallit ja välineet}

Tutkimuskohteena olevan sairaanhoitopiirin alueella infuusiona annettavat lääkehoidot toteutettiin pääasiassa vastaanottotoiminnan yhteydessä arkipäivisin sairaanhoitajan tai lääkärin vastaanotolla. Iltaisin, yöllä ja viikonloppuisin infuusiohoidot toteutettiin joko päivystysvastaanotolla tai vuodeosastolla. Kotisairaalan potilaat saivat lääkehoidon kotonaan tai palvelukodissa suunnitelman mukaisesti arkipäivinä (klo 7-21) kotisairaalan sairaanhoitajan toteuttamana. Yöllä ja viikonvaihteessa infuusiohoidon kotisairaalassa toteutti ensihoitaja. Ensihoitoyksikön osallistumista infuusiohoitojen toteutukseen rajoitti matka potilaan luo, mikä sai olla korkeintaan noin 10 kilometriä ja lisäksi lääkehoitojen määrä oli rajoitettu enimmillään kahteen potilaaseen vuorokaudessa.

Laskimoon annettava lääkehoito toteutettiin potilaan kotona joko ruiskusta annettavana kerta-annoksena (stoosi) tai infuusionesteeseen (esim. 100ml) sekoitettuna. Infusoitava lääkehoito valmistettiin potilaan kotona. Lääkkeet olivat joko sairaanhoitajan/ensihoitajan mukana tai ne säilytettiin potilaan kotona erillisessä pakissa. Potilaan kotona tai kodinomaisissa oloissa lääkehoidon toteutuksessa ei käytetty infuusioautomaatteja. Infuusioautomaattien määrä oli vähäinen ja infuusioautomaattia käytettiin vastaanotoilla ja vuodeosastoilla vain erityistä tarkkuutta vaativissa lääkehoidoissa ja harvoin antibioottihoitojen toteutuksessa.

Potilaan elintoimintojen (sydämen syke, ääreisverenkierron happipitoisuus, hengityksen frekvenssi) monitorointi määräytyi potilaan voinnin mukaan tai lääkehoitoon liittyvien vaikutusten seuraamiseksi. Antibioottihoitojen toteutuksen yhteydessä ei monitoroitu potilaan elintoimintoja, vaan potilaan seuranta perustui silmämääräiseen arvioon.

Kotisairaalatoiminta on kehitetty vastaamaan tarpeeseen, jossa potilaan vaativaakin hoitoa voidaan toteuttaa hänen kotonaan tai kodinomaisissa oloissa palvelukodissa. Esimerkiksi yhdessä tutkimukseen osallistuneessa terveyskeskuksessa vuonna 2012 alkaneen kehitystyön tulos on nähtävissä vuodeosastolla hoidettujen infuusiohoitopotilaiden määrän vähentymisenä (Kuvio 1).

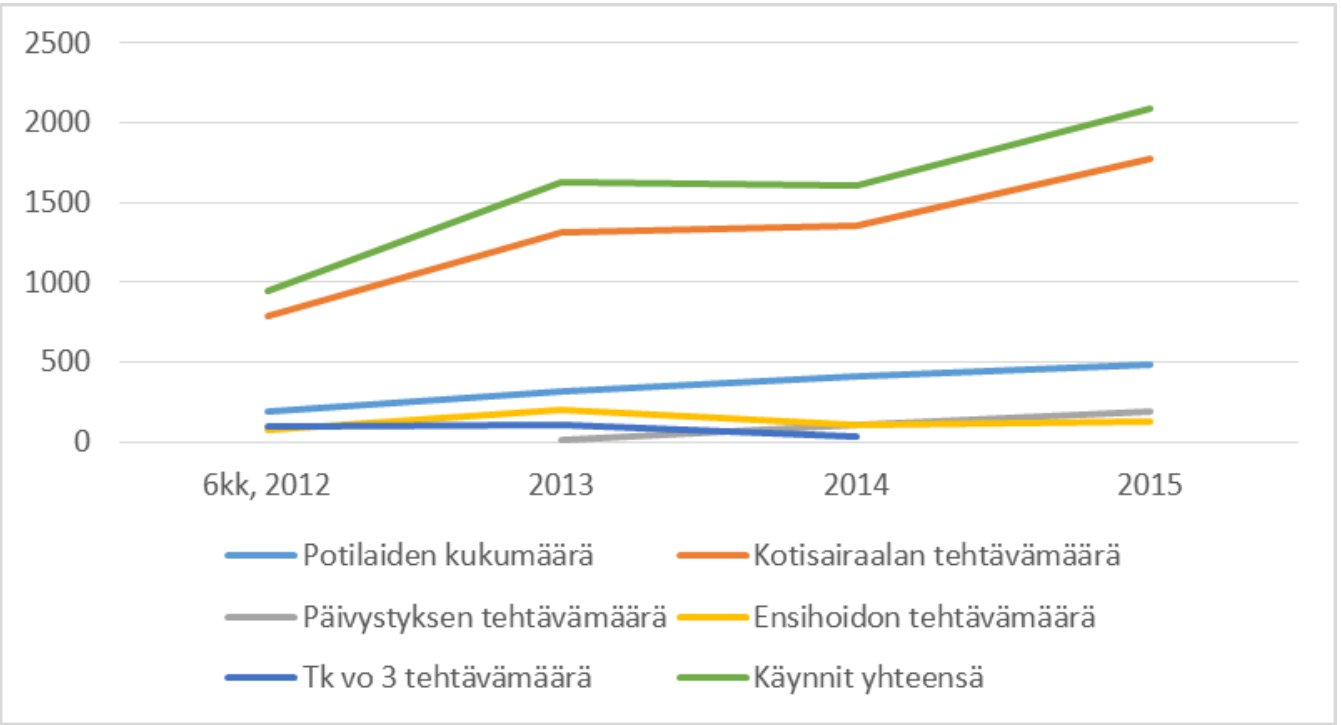

Kuvio 1. Potilas- ja tehtävämäärät, esimerkki perusterveydenhuollosta vuosina 2012-2015 (Tk = terveyskeskus, vo = vuodeosasto) [36]. 
Taulukko 4. Potilaat ohjautuivat kotisairaalaan vuosina 2013-2015 (lukumäärätieto).

\begin{tabular}{lccc}
\hline & $\mathbf{2 0 1 3}$ & $\mathbf{2 0 1 4}$ & $\mathbf{2 0 1 5}$ \\
\hline Erikoissairaanhoito & 12 & 31 & 39 \\
Päivystys & 208 & 182 & 171 \\
Osasto & 28 & & \\
Sisätautien osasto & 12 & 20 & 22 \\
Kirurgian osasto & & & 13 \\
Terveyskeskuksen osastot & 1 & 9 & 11 \\
Vastaanotolta & 6 & 19 & 36 \\
Muu tapa, esim. puhelinsoitto & 46 & 136 & 190 \\
\hline
\end{tabular}

Terveydenhuollon ammattilaiset kokivat haasteellisiksi potilaiden ohjaamisen kotisairaalan potilaiksi. Kotisairaalatoiminnan käynnistämisen yhteydessä oli tehty pitkäkestoista tiedotustyötä, minkä tuloksena oli luotu toimintatapa ohjata potilas kotisairaalan piiriin (Taulukko 4). Potilaat ohjautuvat kotisairaalaan sekä perusterveydenhuollon että erikoissairaanhoidon vuodeosastoilta, mutta ensisijaisesti päivystysvastaanotolta. Aiempi jakso kotisairaalan asiakkuudesta nopeutti potilaan ohjaustumista kotisairaalan piiriin ja usein potilaan ohjaaminen kotisairaalaan sovittiin terveydenhuollon yksiköiden välillä puhelimitse.

\section{Johtopäätökset ja pohdinta}

Tutkimuksessa tavoitettiin kotisairaalatoiminnan kehityksen eri vaiheissa olevia yksiköitä. Yhteistyö ensihoidon kanssa oli edellytys ympärivuorokautiseen kotisairaalatoimintaan $[8,9]$. Kotisairaalatoiminta oli mahdollistanut potilaiden aiemman kotiuttamisen sairaalasta, eikä infuusiohoito edellyttänyt enää vuodeosastohoitoa, jos potilas selviytyi itsenäisesti kotona tai sai avun kotiinsa. Potilaat ohjautuivat kotisairaalan potilaiksi niin poliklinikoilta kuin vuodeosastoilta. Kotisairaalatoiminnan käynnistäminen oli muuttanut potilasvirtoja.

Tutkimuksen kohteena olleissa kunnissa avoterveydenhuollon potilaat saivat infuusiohoidot vuodeosastoilla päivän ja illan aikana ja yöksi he menivät kotiin, niissä kunnissa, joissa ensihoidon palveluja ei ollut saatavilla
24 tuntia vuorokaudessa. Vaihtoehtoisesti potilaat hakivat infuusiohoidot vastaanotolta kerran tai useammin päivässä ja viikonloppuisin infuusiohoidot toteutettiin päivystysvastaanotolla. Infuusiohoitojen toteutus ja toimintamallit avohoidoissa vaihtelivat eri terveyskeskuksissa.

Tutkimuksessa saatiin näkyväksi avoterveydenhuollossa toteutettavien infuusiohoitojen määrä ja yleisin infuusiohoito oli antibioottihoito. Tämän tutkimuksen perusteella ensisijainen kehittämiskohde on vastaanotoilla infuusiohoitoja saavat 18-64-vuotiaat potilaat. Tästä ryhmästä olisi mahdollista löytää itsehoitoon sitoutuvia ja älykästä teknologiaa käyttäviä henkilöitä tai heidän läheisiä.

Potilasvalinta kotisairaalan potilaaksi nosti esille useita kysymyksiä. Terveydenhuollon ammattilaiset totesivat, että heiltä puuttuu selkeä käytäntö siitä, milloin toimintaa nimitetään kotisairaalatoiminnaksi, kotihoidoksi tai tehostetuksi kotisairaanhoidoksi [6]. Potilaan kannalta tärkeintä on, että hän saa tarvitsemansa hoidon turvallisesti. Käypä hoito - suositukset auttavat potilaiden ohjaamisessa kotihoitoon tai kotisairaalan potilaaksi (esimerkiksi http://www.kaypahoito.fi), mutta edelleen puuttuu arjen työtä ja toiminnan seurantaa tukevat kriteerit.

Kotisairaalatoiminnan kustannusten jakautuminen ja potilaslaskutus koettiin epäselväksi, mihin SOTEuudistuksen odotetaan tuovat selkeyttä. Sosiaali- ja terveydenhuollossa tehdyt rakenteelliset muutokset 
eivät välttämättä ole johtaneet toivottuun yhteistyöhön [6]. Muutos kotisairaalatoiminnan ja ensihoidon yhteistyössä näkyi muutoksena vuodeosastolle ohjautuvien potilaiden määrän vähenemisenä. Etämonitorointi ja älykäs teknologia voisivat tuoda vaihtoehdon käytettävissä olevien resurssien riittävyyteen.

Saumattomasti yhteen toimivat tietojärjestelmät edellyttävät yhtenäistä infostruktuuripohjaa, jossa käytetään yhteisesti sovittuja tietorakenteita ja standardeja [29]. Tässä selvityksessä organisaatioiden sisällä tunnistettiin yksikkökohtaisia toiminta- ja kirjaamistapoja, mitkä vaikuttivat tiedon saatavuuteen. Sosiaali- ja terveystietojen yhdistämisen ongelmat on tunnistettu jo aiemmin [30] ja lisäksi tietoa pitäisi pystyä summaamaan ja listaamaan potilaskohtaisista tiedoista toiminnan seurantaan, kehittämiseen sekä tutkimukseen. Tiedonsaantimahdollisuudet eri sosiaali- ja terveydenhuollon organisaatioiden välillä vaihtelivat $10-40$ prosenttiin vuoden 2014 arviossa ja arviot yksityisten palvelutuottajien osalta tiedonsaantimahdolliset olivat julkisia toimijoitakin heikommat [30].

Kotihoidossa työnsisältö on muuttunut viime vuosina ja tulevan sote-muutoksen myötä se muuttuu edelleen. Esimerkiksi Eksotessa verkosto on syntynyt asiakkaan ympärille [31]. Eri ammattiryhmien vahvuutta hyödynnetään verkostossa, jossa terveydenhuollon ammattilainen liikkuu yksin asiakkaiden luona. Suomessa sosiaali- ja terveydenhuollon palveluintegraatioita on tehty pitkään, mutta muutosprosessien vaikutuksia on raportoitu vähän ja tietoa ei ole saatu laajempaan käyttöön [32].

Digitalisaation ja uudenlaisten asiointikanavien odotetaan ylittävän maantieteellisiä etäisyyksiä ja tuovan palvelut lähelle kansalaisia [30]. Infuusiohoidon toteutuksessa etämonitoroinnin haasteena ovat harvaan asutulla maaseudulla ja pitkien matkojen takana asuvat potilaat, jossa tietoliikenneyhteydet eivät ole vielä arkipäivää. Lisäksi haasteena on niin väestön kuin sosiaalija terveydenhuollon ammattilaisten motivaatio, taidot ja välineet sähköisen asioimisen lisäämiseen. Erilaiset "äly-terveysrannekkeet" ovat arkipäivää ja niiden hinnat ovat kohtuullisia. Olisi mielekästä etsiä näistä välineistä ratkaisuja. Tämän tutkimuksen perusteella ter- veydenhuollon ammattilaiset olivat kiinnostuneita hyödyntämään älykästä teknologiaa nykyistä enemmän. Haasteena pidettiin osaamisvalmiuksia, koulutusta ja tuen saantia niin sosiaali- ja terveydenhuollon ammattilaisille kuin kansalaisille sekä sopivien laitteiden puuttuminen [33-35].

Kotisairaalatoiminnan kehittäminen on luonut Suomeen uusia toimintamalleja. Eri paikkakunnilla uusien toimintamallien potilaspalaute on ollut myönteistä ja potilasvirtojen muutokset ovat vaikuttaneet niin vuodeosastojen kuin vastaanottojen kuormitukseen $[8,9,15,36]$. Tämän tutkimuksen tulokset voidaan tiivistää kolmeen suositukseen: 1) älykkään teknologian lisääminen, 2) yhteistyön lisääminen ja kehittäminen sekä 3) toimintamallien kehittäminen.

\section{Lähteet}

[1] World Health Organization (WHO). mHealth - New horizons for health through mobile technologies. World Health Organization (WHO); 2011. Saatavilla: http://www.who.int/goe/publications/goe_mhealth_w eb.pdf.

[2] ETENE 2010. Teknologia ja etiikka sosiaali- ja terveysalan hoidossa ja hoivassa. ETENE-julkaisuja 30. Saatavilla: http://urn.fi/URN:ISBN:978-952-00-3081-0.

[3] Mäkelä T, Uusimaa P, Koivisto UM, Raatikainen P. Etäseurannan mahdollisuudet rytmihäiriöpotilaan hoidossa. Duodecim 2009;125:2059-2065.

[4] Koivisto UM, Raatikainen P. 2011. Rytmihäiriötahdistinpotilaiden etäseuranta. Sydänääni 2011;22:1A.

[5] McLean S, Sheikh A, Cresswell K, Nurmatov U, Mukherjee M, Hemmi A, Pagliari C. The Impact of Telehealthcare on the Quality and Safety of Care: A Systematic Overview. PLoS ONE 2013;8(8):e71238. https://doi.org/10.1371/journal.pone.0071238

[6] Paljärvi S. Muuttuva kotihoito. 15 vuoden seurantatutkimus Kuopion kotihoidon organisoinnista, sisällöstä ja laadusta. Dissertations in Social Sciences and Business Studies No 39. Publications of the University of Eastern Finland; 2012. 
[7] Valvira. Sosiaali- ja terveysalan lupavirasto. 2015. Saatavilla: http://www.valvira.fi/

[8] Hartikainen T, Eskelinen J, Kurola J, Rieppo J, Paakkonen $\mathrm{H}$, Asikainen $\mathrm{U}$. Ensihoidon integraatio osaksi terveydenhuollon palvelujärjestelmää: Kotisairaalahanke ja sen kustannustehokkuuden arviointi. "EnTerhanke" Loppuraportti 3.2.2015. Pohjois-Savon sairaanhoitopiiri, Ensihoitokeskus; 2015.

[9] Kallio T, Miettinen E. Kuopion kotisairaalapilottihanke; Sairaanhoitajien ja ensihoitajien yhteistyön toimivuus ja ammatilliset valmiudet. Opinnäytetyö, Savoniaammattikorkeakoulu; 2014.

[10] Seaton RA, Barr DA. Outpatient parenteral antibiotic therapy: Principles and practice. Eur J Intern Med 2013; 24:617-623. https://doi.org/10.1016/j.ejim.2013.03.014

[11] Chapman ALN, Seaton RA, Cooper MA, Hedderwick S, Goodall V, Reed C, Sanderson F, Nathwani D. Good practice recommendations for outpatient parenteral antimicrobial therapy (OPAT) in adults in the UK: a consensus statement. J Antimicrob Chemother 2012; 67:1053-1062. https://doi.org/10.1093/jac/dks003

[12] Kieran J, O’Reilly A, Parker J, Clarke S, Bergin C. Self-administered outpatient parenteral antimicrobial therapy: a report of three years' experience in the Irish healthcare setting. Eur J Clin Mikrobiol Infect Dis 2009;28:1369-1375. https://doi.org/10.1007/s10096009-0794-5

[13] Szeinbach SL, Pauline J, Villa KF, Commerford SR, Collins A, Seoane-Vazquez E. Evaluating catheter complications and outcomes in patients receiving home parenteral nutrition. J Eval Clin Pract. 2015 Feb;21(1):153-159. https://doi.org/10.1111/jep.12264

[14] Saari H, Ryynänen O-P, Lönnroos E, Kokko S. GP run local hospitals in Finland. The basic functions and the role in the hospital system. Family doctors with heads and hearts. WONCA Europe conference 15-18 June 2016 Denmark. Saatavilla: http://www.woncaeurope2016.com/.

[15] Agge E. Kotisairaalan vapaa ja itsenäinen. Sairaanhoitajalehti 2/2016 2016.
[16] International Electrotechnical Commission (IEC) 606011-1. Medical electrical equipment-Part 1-11: General requirements for basic safety and essential performance - Collateral Standard: Requirements for medical electrical equipment and medical electrical systems used in the home healthcare environment. Helsinki: SFS Suomen standardisoimisliitto; 2015. Saatavilla:

https://webstore.iec.ch/preview/info_iec60533\%7Bed3 $.0 \% 7 D e n . p d f$.

[17] Ammenwerth E, Aly AF, Burkle T, Christ P, Dormann $\mathrm{H}$, Friesdorf $\mathrm{W}$, et al. Memorandum on the use of information technology to improve medication safety. Methods Inf Med. 2014;53(5):336-343. https://doi.org/10.3414/ME14-01-0040

[18] Ohashi K, Dalleur O, Dykes PC, Bates DW. Benefits and Risks of Using Smart Pumps to Reduce Medication Error Rates: A Systematic Review. Drug Saf. 2014 Dec;37(12):1011-1020. https://doi.org/10.1007/s40264-014-0232-1

[19] Magrabi F, Aartsb J, Nohrc C, Bakerd M, Harrisond S, Pelayoe S, Talmonf J, Sittig DF, Coieraa E. A comparative review of patient safety initiatives for national health information technology. Int J Med Inform. 2013 May;82(5):e139-148.

https://doi.org/10.1016/j.ijmedinf.2012.11.014

[20] Palojoki S, Mäkelä M, Lehtonen L, Saranto K. An analysis of electronic health record-related patient safety incidents. Health Informatics J. 2016 Mar 7. pii: 1460458216631072.

https://doi.org/10.1177/1460458216631072

[21] THL. Turvallinen lääkehoito. Opas lääkehoitosuunnitelman tekemiseen sosiaali- ja terveydenhuollossa. (toim.) Inkinen R, Volmanen $\mathrm{P}$, Hakoinen S. Terveyden ja hyvinvoinnin laitos (THL); 2015. Saatavilla: http://URN:ISBN:978-952-302-577-6.

[22] ISMP - Institute for Safe Medication Practices. Proceedings from the ISMP summit on the use of smart infusion pumps: Guidelines for safe implementation and use. ISMP - Institute for Safe Medication Practices; 2009

Saatavilla: 
https://www.ismp.org/Tools/guidelines/smartpumps/c omments/default.asp.

[23] Savastano M, Hovsto A, Pharow P, Blobel B. Identity-management factors in e-health and telemedicine applications. J Telemed Telecare. 2008;14(7):386-388. https://doi.org/10.1258/jtt.2008.007014

[24] Garg V, Brewer J. Telemedicine Security: A Systematic Review. J Diabetes Sci Technol. 2011 May 1;5(3):768-777.

https://doi.org/10.1177/193229681100500331

[25] Zetter K. Hacker can send fatal dose to hospital drug pumps. $2015 . \quad$ Saatavilla: https://www.wired.com/2015/06/hackers-can-sendfatal-doses-hospital-drug-pumps/.

[26] Khera M. Think Like a Hacker: Insights on the Latest Attack Vectors (and Security Controls) for Medical Device Applications. J Diabetes Sci Technol. 2017 Mar;11(2):207-212.

https://doi.org/10.1177/1932296816677576

[27] Ruotsala M. Haastattelu 29.9.2016. Päällikkö, tietoturvapalvelut. Istekki Oy; 2016.

[28] Rautiainen H, Saukkonen S-M. AvoHILMO. Peruterveydenhuollon avohoidon ilmoitus 2013. Määrittelyt ja ohjeistus. Terveyden ja hyvinvoinnin laitos; 2012. Saatavilla: http://urn.fi/URN:ISBN:978-952-245-765-3

[29] Sosiaali- ja terveysministeriö. Tieto hyvinvoinnin ja uudistuvien palvelujen tukena. SOTE-tieto hyötykäyttöön -strategia 2020. Tampere: Sosiaali- ja terveysministeriö; $2014 . \quad$ Saatavilla: https://www.julkari.fi/bitstream/handle/10024/125500 /URN_ISBN_978-952-00-3548-8.pdf?sequence=1.

[30] Hyppönen H, Ilmarinen K. Sosiaali- ja terveydenhuollon digitalisaatio. Tutkimuksesta tiiviisti 22/2016. Helsinki: Terveyden ja hyvinvoinnin laitos; 2016.
[31] Eksote. Yhden hengen liikkuva päivystysyksikkö aloittaa Eksotessa. Eksote; 2016. Saatavilla: http://www.eksote.fi/eksote/ajankohtaista/2016/Sivut/ Yhden-hengen-liikkuva-p\%C3\%A4ivystysyksikk\%C3\%B6aloittaa-Eksotessa.aspx

[32] Virtanen P, Smedberg J, Nykänen P, Stenvall J. Palvelu- ja asiakastietojärjestelmien integraation vaikutukset sosiaali- ja terveyspalveluissa. Valtioneuvoston selvitus- ja tutkimustoiminnan julkaisusarja 2/2017. Saatavilla:

http://tietokayttoon.fi/julkaisu?pubid=16201.

[33] Bates DW, Bitton A. The Future of Health Information Technology in the Patient-Centered Medical Home. Health Aff (Millwood). 2010 Apr;29(4):614-21. https://doi.org/10.1377/hlthaff.2010.0007

[34] Parker E, Zimmerman S, Rodrigues S, Lee T. Exploring Best Practices in Home Health Care: A Review of Available Evidence on Select Innovations. Home Health Care Management \& Practice 2014;26(1):17-33. https://doi.org/10.1177/1084822313499916

[35] Aura M, Sormunen MST, Jordan SE, Tossavainen KA, Turunen HE. Learning Outcomes Associated With Patient Simulation Method in Pharmacotherapy Education. An Integrative Review. Simul Healthc. 2015 Jun;10(3):170-177.

https://doi.org/10.1097/SIH.0000000000000084

[36] Kivekäs E, Kokki H, Mäntyselkä P, Saranto K. Turvallisesti kotona ja laitoksessa -hanke. Etämonitoroinnin ja smart-pump teknologian hyödyntäminen infuusiona annettavassa hoidossa. Pohjois-Savon liitto; 2017. Saatavilla: http://urn.fi/URN:ISBN:978-952-61-2440-7. 